\title{
The Analysis on the Current Situation and Countermeasures of Tourism Antipoverty Management in Ethnic Villages
}

Jing Lu

Guangxi International Business Vocational College, LaiBin 530007, Guangxi, China.

Abstract: Because of their unique cultural heritage and natural environment, ethnic villages have gradually become "hot spots" in our country's tourism industry. In order to better develop the tourism industry in ethnic villages and help more villagers get rid of poverty and become rich, our country has attached great importance to poverty alleviation projects of tourism in ethnic villages in recent years. This paper starts from the analysis on the current situation of antipoverty management of tourism in ethnic villages, focuses on the description of management countermeasures of tourism antipoverty in ethnic villages, hoping to further activate the tourism industry of ethnic villages in our country and bring better life to local villagers.

Keywords: Ethnic Minorities; Village Tourism; Antipoverty Management

At this stage, combining the unique cultural heritage and natural environment of ethnic villages to carry out "tourism antipoverty" is one of the main ways for the poor ethnic population in our country to get rid of poverty and become rich. However, in reality, although some ethnic villages have developed some tourism industries and have received support from relevant departments, they have not really solved the problem of "getting rid of poverty" for most villagers. Only by facing up to the current problems in antipoverty of tourism can we better implement the specific work of tourism antipoverty and achieve better results.

\section{The Analysis on the current management situation of tourism antipoverty in ethnic villages}

\subsection{It is difficult for the poor to participate}

Currently, it is difficult for poor families to participate in tourism antipoverty projects in some ethnic villages. There are two main reasons for this: On the one hand, in some ethnic villages tourism antipoverty projects, local leaders will introduce a large number of foreign companies and workers in order to quickly build a tourism industry, and they do not give local villagers corresponding supports. Without the support of relevant departments, poor local families have no resources and conditions, making it difficult to participate in the tourism industry. On the other hand, in some tourism antipoverty projects in ethnic villages, local leaders encourage poor people to actively participate in tourism industry, but there is no standardized training for poor people, resulting in these people not having the experience and ability to engage in the tourism industry.

\subsection{It is difficult for local villagers to get rid of poverty and become rich}

The tourism antipoverty project in ethnic villages is carried out mainly to help local villagers get rid of poverty and become rich. However, in actual conditions, it is difficult for local villagers in some ethnic villages to truly get rid of poverty from tourism antipoverty projects. The main manifestations are as follows: Firstly, in some ethnic village tourism antipoverty projects, the main benefiters are mainly local enterprises, and related government units, while the local villagers do not have a good entry point to obtain benefits. Some villagers can earn a certain amount of income by working in tourism enterprises, but the income is not much, which cannot really meet the needs of poor families; Secondly, in some ethnic village tourism antipoverty projects, local villagers lack marketing concepts, management thinking, in the face of increasingly fierce

Copyright(C) 2020 Jing Lu

doi: 10.18686/ahe.v4i10.2901

This is an open-access article distributed under the terms of the Creative Commons Attribution Non-Commercial License (http://creativecommons. org/licenses/by-nc/4.0/), which permits unrestricted non-commercial use, distribution, and reproduction in any medium, provided the original work is properly cited. 
competition in the tourism market, so they do not know how to attract tourists, leading to the self-operated tourism industry being unable to gain benefits, and even making a loss.

\section{The research on the countermeasures of tourism antipoverty management in ethnic villages}

\subsection{Encourage poor people to participate in the tourism industry in accordance with the measure of "one policy per household"}

The core goal of "tourism antipoverty " is to help the poor get rid of poverty and become rich. Therefore, relevant departments should encourage poor people to actively participate in the tourism industry. On the one hand, in the tourism antipoverty project in ethnic villages, local leaders must adhere to the combination of "bringing in" and "going out", not only introducing some outstanding tourism companies and professionals, but also encouraging local villagers to actively participate in the tourism industry. Especially for poor families, the local area can introduce some special assistance policies. For example, in accordance with the measure of "one policy per household", every family is given the right to participate in the tourism industry equally; On the other hand, in the tourism antipoverty project in ethnic villages, local leaders should not only verbally encourage poor people to actively participate in the tourism industry, but also establish a complete training system, carrying out large-scale "tourism industry development training" to enrich the knowledge structure of local villagers, and improve the ability of local villagers to independently manage the tourism industry.

\subsection{Organize local villagers to learn about "modern operation" and enable local villagers to take the lead in getting rid of poverty and becoming rich}

In order to enable local villagers to take the lead in getting rid of poverty and becoming rich, the local area can work hard in these areas: Firstly, in the antipoverty project in ethnic villages, the local government must grasp the ratio of "foreign enterprises" to "local enterprises", and encourage enterprises in the villages to give priority to hiring local villagers and create more employment opportunities for local villagers. Regarding the salary and welfare of local villagers, the local government should also conduct reasonable supervision to avoid "too low salary" affecting the quality of life of the villagers; Secondly, in the antipoverty project in ethnic villages, for the tourism industry independently operated by local villagers, relevant departments can regularly organize the responsible persons in these industries to learn the knowledge of "modern operation", use modern marketing concepts and management thinking to improve the competitiveness of the industry, achieving better economic benefits, and truly achieving the goal of "get rid of poverty".

\subsection{Create a diversified industrial chain of "tourism +" and improve the tourism industrial chain of antipoverty}

How to further improve the tourism industry chain of antipoverty in ethnic villages? On the one hand, in the tourism antipoverty project in ethnic villages, the local government should encourage the diversified and innovative development of the tourism industry to rationally plan the layout of the tourism industry chain from "visiting", "catering", "games", "picking", "fishing", "greening" and other aspects. In addition, the local tourism industry can also combine local characteristics to create "differentiated" tourism features to better meet tourists with different needs; On the other hand, in the tourism antipoverty project in ethnic villages, relevant departments must the consciousness of integrating resources, combined with various advantageous resources in the village, realizing the "tourism +" industrial chain, such as tourism + cultural visits, tourism + sports games, tourism + farmhouse, etc., so that tourists can have a richer and fresher experience.

\section{Conclusion}

By actively carrying out "tourism antipoverty", many ethnic villages in our country have gained new economic growth points, and the lives of villagers are getting better and better. However, from the perspective of longer-term goals, the road of "tourism antipoverty" should be more stable and precise. In this process, the relevant departments must not only pay attention to economic benefits, but also pay attention to the ecological environment. It is necessary to remember not to seek development at the expense of the environment. The road to antipoverty in ethnic villages should be a sustainable development road.

\section{References}

1. Zhang L, Shao JF. Research on the significance, predicament and path of developing rural tourism from the perspective of targeted antipoverty. Agricultural Economics 2019; (03): 30-32.

2. Lin N. Research on the integrative development strategy of rural tourism and precision antipoverty under the background of "Tourism E-commerce +". Tourism Forum 2018; (06): 92-98. 